\title{
Aplikasi Panduan Ibadah Haji Berbasis Android
}

\author{
Deddy Sucipta Syahril, R. Rizal Isnanto*), Rinta Kridalukmana \\ Program Studi Sistem Komputer, Fakultas Teknik, Universitas Diponegoro \\ Jl. Prof. Soedarto, SH, Kampus Undip Tembalang, Semarang, Indonesia 50275
}

\begin{abstract}
This is an application for hajj guidance based on Android. The application is made using software Eclipse IDE and Android SDK with Java as a programming language. Stage of development software used is SDLC (Software Development Life Cycle) by using the method waterfall, as modeling software used is UML (Unified Modelling Language). Steps in this research are software requirement analysis, design, coding, and system testing. Functional testing using a method of black box. The result of this research is an application of hajj guidance based on Android can be use to guide in hajj. The application can run well on a device with a minimum of Android operating system version 4.2 (Jelly Bean) with the storage space available at least $25 \mathrm{MB}$. Function menus and buttons is operated appropriately according to their functions. This application for hajj guidance can be used as a medium to help moslems in hajj.
\end{abstract}

Keywords - Android; Hajj Guidance; Eclipse; SDLC; UML

\section{Pendahuluan}

$\mathrm{H}$ aji adalah salah satu rukun Islam yang kelima. Menunaikan ibadah haji adalah bentuk ritual tahunan bagi kaum muslim yang mampu secara material, fisik, maupun keilmuan dengan berkunjung ke beberapa tempat di Arab Saudi dan melaksanakan beberapa kegiatan pada satu waktu yang telah ditentukan yaitu pada bulan Dzulhijjah. Hal ini sesuai dengan firman Allah dalam Q.S Ali Imran: 97 yang artinya: "Padanya terdapat tanda-tanda yang nyata, (diantaranya) maqam Ibrahim; barangsiapa memasukinya (Baitullah itu) menjadi amanlah dia; mengerjakan haji adalah kewajiban manusia terhadap Allah, yaitu (bagi) orang yang sanggup mengadakan perjalanan ke Baitullah; Barangsiapa mengingkari (kewajiban haji), maka sesungguhnya Allah Maha Kaya (tidak memerlukan sesuatu) dari semesta alam. [4]

Ibadah haji dalam tata aturannya mempunyai syarat dan rukun yang harus dikerjakan secara sempurna. Hal ini sesuai dengan firman Allah dalam Q.S Al-Baqarah: 196 yang artinya: "Dan sempurnakanlah ibadah haji dan umrah karena Allah. Jika kamu terkepung (terhalang oleh musuh atau karena sakit), maka (sembelihlah) qurban yang mudah didapat, dan jangan kamu mencukur kepalamu, sebelum qurban sampai di tempat penyembelihannya. Jika ada di antaramu yang sakit atau ada gangguan di kepalanya (lalu ia bercukur), maka wajiblah atasnya berfidyah, yaitu: berpuasa atau bersedekah atau berqurban. Apabila kamu telah (merasa) aman, maka bagi siapa yang ingin mengerjakan umrah sebelum haji (di dalam bulan haji), (wajiblah ia menyembelih) korban yang mudah didapat. Tetapi jika ia tidak menemukan (binatang korban atau tidak mampu), maka wajib berpuasa tiga hari dalam masa haji dan tujuh hari (lagi) apabila kamu telah pulang kembali. Itulah sepuluh (hari) yang sempurna. Demikian itu (kewajiban membayar fidyah bagi orang-orang yang keluarganya tidak berada (di sekitar) Masjidil Haram (orang-orang yang bukan penduduk kota Mekah). Dan bertakwalah kepada Allah dan ketahuilah bahwa Allah sangat keras siksaan-Nya”.

Haji adalah amal ibadah yang dilakukan dengan sengaja mengunjungi Baitullah di Mekkah dengan ikhlas mengharap keridhaan Allah dengan syarat dan rukun tertentu. Menunaikan ibadah haji adalah melakukan rukun islam yang kelima, oleh sebab itu hukumnya wajib bagi setiap orang islam sekali dalam seumur hidup bagi yang mampu melaksanakannya. ${ }^{[10]}$

Ibadah Haji merupakan simbol-simbol yang harus dihayati, bukan sekadar kegiatan gerak-gerik tanpa makna. Kegiatan dan gerak tersebut perlu dilakukan dengan tata cara yang benar, sesuai ketentuan yang diajarkan. Tanpa kesesuaian dengan ketentuan yang ditetapkan-Nya, maka ibadah tersebut tidak akan berarti di sisi-Nya.

Berhaji merupakan sikap ruhani dan perilaku imani yang mestinya menjadikan calon haji merasa damai dengan diriNya, tenang menuju ke tujuan serta rela meninggalkan yang ditinggal. Karena itulah maka yang pertama dan utama dituntut adalah ketulusan hati. Niat berhaji hanya karena Allah swt. seharusnya sudah menyertai tamu Allah swt. sejak terbetik keinginannya untuk berkunjung. Apabila ketika itu masih belum mantap, semoga dimantapkan ketika melangkahkan kaki dari rumah. Ketulusan niat karena Allah swt. itu harus telah menyertai setiap tamu Allah swt. ketika telah mengenakan pakaian ihram, sambil mengucapkan: "Labbaik Allahuma Hajjan", yang artinya: "Aku datang memenuhi panggilan-Mu ya Allah untuk berhaji”. [10]

Calon jamaah haji harus mendapatkan pembelajaran dan panduan agar ibadah haji yang dilakukan sempurna. Buku panduan ibadah haji yang telah dikemas oleh pemerintah dan dibagikan kepada calon jamaah haji merupakan bentuk pedoman dan informasi mengenai tata cara melaksanakan ibadah haji di tanah suci, namun banyak di kalangan para calon jamaah haji menganggap buku panduan haji tersebut kurang praktis ditambah dengan aktivitas yang padat buku ini jarang terbawa dan dibaca. Aplikasi panduan ibadah haji yang dapat diakses menggunakan telepon selular tentu akan lebih ptraktis dan mudah digunakan. ${ }^{[5]}$

Tujuan dari penelitian ini adalah membangun sebuah program aplikasi panduan Ibadah Haji berbasis Android yang dapat digunakan untuk mempermudah para jamaah maupun calon jamaah haji tentang pelaksanaan ibadah haji yang sesuai dengan tuntunan.

\section{Metode Penelitian}

\section{Perancangan Menggunakan Metode Waterfall}

Metode waterfall adalah metode yang menyarankan sebuah pendekatan sistematis dan sekuensial melalui tahapantahapan yang ada pada SDLC untuk membangun sebuah perangkat lunak. Metode ini memberikan pendekatanpendekatan sistematis dan berurutan bagi pengembangan

*) Penulis korespondensi (R. Rizal Isnanto)

Email: rizal_isnanto@undip.ac.id 
perangkat lunak. Model waterfall terdiri dari 5 tahap yaitu Analisis, Desain, Pengkodean, Pengujian dan Pemeliharaan. [6]

\section{Analisis Kebutuhan}

Sistem yang dibuat seringkali tidak sesuai dengan keinginan dari pengguna sistem yang memungkinkan terjadi kesalahan. Hal ini sering terjadi apabila dalam pembuatan sebuah sistem tidak diawali dengan analisis kebutuhan yang mendasar dan rinci. Analisis kebutuhan dapat dilakukan melalui wawancara dengan pihak-pihak terkait dan pengamatan dari lingkungan di mana sistem akan dibangun.

Aplikasi yang akan dibuat merupakan sebuah sistem panduan ibadah haji pada perangkat bergerak berbasis Android. Aplikasi ini dibuat berbasis mobile dengan perangkat pengembangan Eclipse dan pemrograman bahasa Java.

Java merupakan bahasa pemrograman yang dapat dijalankan di berbagai komputer termasuk telepon seluler. Bahasa ini banyak mengadopsi sintaksis yang terdapat pada $\mathrm{C}$ dan $\mathrm{C}++$, namun dengan sintaksis model objek yang lebih sederhana serta mendukung rutin (user program) pada tingkat dasar. Java memperkenalkan diri sebagai bahasa pemrograman yang mendukung konsep Object Oriented Programming (OOP) secara total. Maksudnya adalah bahwa sejak awal mula Java diciptakan, Java memang dibuat untuk mendukung konsep OOP tersebut. Oleh karena itu, struktur bahasa pemrograman Java harus memiliki sebuah kelas utama dan sebuah metode utama (main method). Semboyan utama Java yang terkenal adalah Write Once Run Everywhere. Maksudnya cukup dengan menuliskan kode sumber sekali saja pada sebuah komputer, maka akan dapat menjalankannya pada komputer lain yang memiliki JVM (Java Virtual Machine). Hal ini dapat melambangkan portabilitas Java yang sangat mudah dilakukan. ${ }^{[3]}$

Eclipse Integrated Development Environment (Eclipse IDE) adalah program komputer yang memiliki beberapa fasilitas yang diperlukan dalam pembangunan perangkat lunak. Tujuan dari IDE adalah untuk menyediakan semua utilitas yang diperlukan dalam membangun perangkat lunak. ${ }^{[9]}$

Eclipse merupakan IDE yang paling banyak diadopsi untuk programmer Java. Dan sekarang Eclipse adalah IDE yang lebih disukai untuk mengembangkan aplikasi android. Eclipse menyediakan lingkungan yang komprehensif bagi pengembang Android untuk membuat aplikasi. Berikut ini adalah sifat dari Eclipse.

1. Multi-platform: Target sistem operasi Eclipse adalah Microsoft Windows, Linux, Solaris, AIX, HPUX dan Mac OS X.

2. Mulit-language: Eclipse dikembangkan dengan bahasa pemrograman Java, akan tetapi Eclipse mendukung pengembangan aplikasi berbasis bahasa pemrograman lainnya, seperti C/C++, Cobol, Python, Perl, PHP, dan lain sebagainya.

3. Multi-role: Selain sebagai IDE untuk pengembangan aplikasi, Eclipse pun bisa digunakan untuk aktivitas dalam siklus pengembangan perangkat lunak, seperti dokumentasi, test perangkat lunak, pengembangan web, dan lain sebagainya. ${ }^{[2]}$

Beberapa kebutuhan non fungsional perihal pengembangan aplikasi.

1) Notebook TOSHIBA Intel ${ }^{\circledR}$ Core $^{\mathrm{TM}} 2$ Duo

2) Sistem Operasi : Microsoft Windows 8.1 Professional

3) Ponsel pintar Alcatel OneTouch Flash Plus dengan OS Android Lollipop dan RAM 2 GB
4) Eclipse IDE

5) Android SDK

6) Corel Draw

\section{Desain}

Perancangan konseptual meliputi desain proses dari sistem. Desain proses dibuat berdasarkan kebutuhan fungsional dan kebutuhan data. Aliran Sistem digambarkan dengan menggunakan UML (Unified Modelling Language)

\subsection{Use Case Diagram}

Use case diagram menggambarkan fungsionalitas yang diharapkan dari sebuah sistem. Use case menunjukan sebuah interaksi antara aktor dengan sistem. Use case diagram ditunjukan oleh Gambar 1.

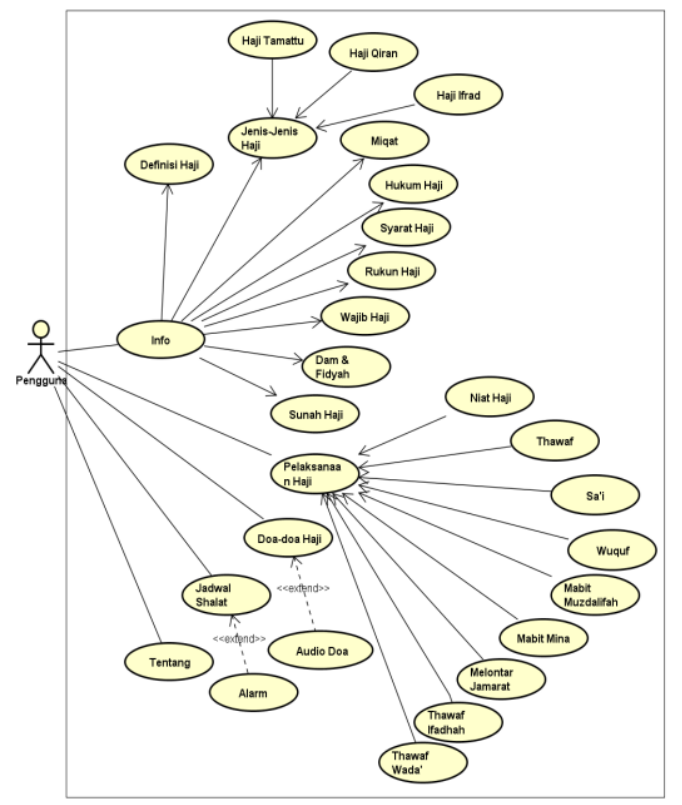

Gambar 1. Use case Diagram

\subsection{Sequence Diagram Info}

Sequence diagram menu Info ditunjukan oleh Gambar 2. Pada Gambar 2 terlihat bahwa pada saat aplikasi dibuka menampilkan menu Utama aplikasi yang dapat dilihat pengguna. Pengguna memberikan masukan dengan memilih menu Info sehingga aplikasi akan menjalankan methode MenuInfo dan methode onCreate untuk menampilkan menu Info.

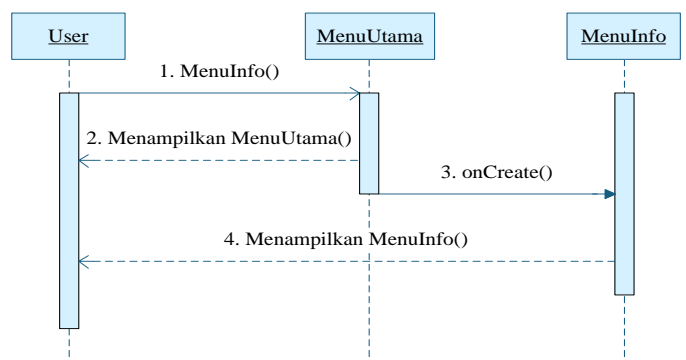

Gambar 2. Sequence Diagram Info

\subsection{Sequence Diagram Definisi Haji}

Sequence diagram menu Definisi Haji ditunjukan oleh Gambar 3. Pada Gambar 3 terlihat bahwa pada saat aplikasi dibuka menampilkan menu Utama aplikasi yang dapat dilihat pengguna. Pengguna memberikan masukan dengan memilih menu Info sehingga aplikasi akan menjalankan methode MenuInfo untuk menampilkan menu Info. 
Selanjutnya pengguna memilih tombol Definisi Haji untuk menjalankannya digunakan methode Definisi dan methode onCreate menampilkan halaman pengertian dari definisi haji.

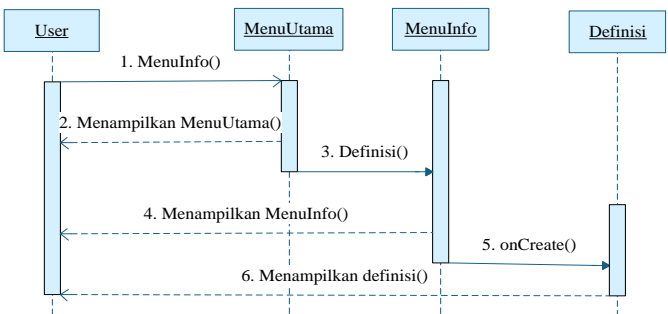

Gambar 3. Sequence Diagram Definisi Haji

\subsection{Sequence Diagram Jenis-Jenis Haji}

Sequence diagram menu Jenis-Jenis Haji ditunjukan oleh Gambar 4. Pada Gambar 4 terlihat bahwa pada saat aplikasi dibuka menampilkan menu Utama aplikasi yang dapat dilihat pengguna. Pengguna memberikan masukan dengan memilih menu Info sehingga aplikasi akan menjalankan methode MenuInfo untuk menampilkan menu Info. Selanjutnya pengguna memilih tombol Jenis-jenis Haji untuk menjalankannya digunakan methode Jenis dan methode onCreate untuk menampilkan menu Jenis-Jenis Haji.

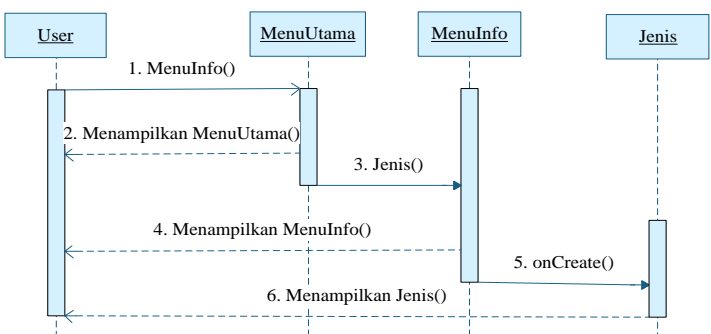

Gambar 4. Sequence Diagram Jenis-Jenis Haji

\subsection{Sequence Diagram Pelaksanaan Haji}

Sequence diagram menu Pelaksanaan Haji ditunjukan oleh Gambar 5. Pada Gambar 5 terlihat bahwa pada saat aplikasi dibuka menampilkan menu Utama aplikasi yang dapat dilihat pengguna. Pengguna memberikan masukan dengan memilih menu Pelaksanaan Haji sehingga aplikasi akan menjalankan methode MenuPelaksanaan dan methode onCreate untuk menampilkan menu Pelaksanaan Haji.

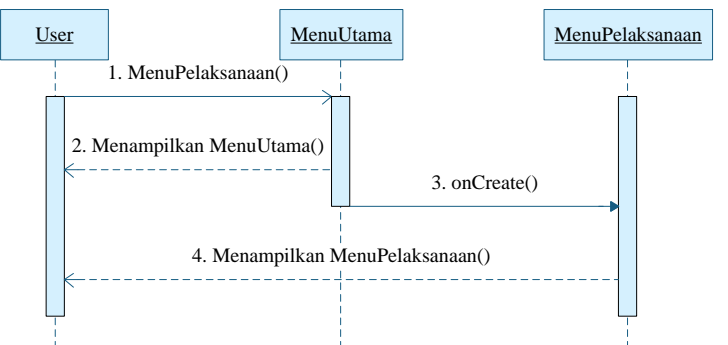

Gambar 5. Sequence Diagram Pelaksanaan Haji

\subsection{Sequence Diagram Niat Haji}

Sequence diagram menu Niat Haji ditunjukan oleh Gambar 6. Pada Gambar 6 terlihat bahwa pada saat aplikasi dibuka menampilkan menu Utama aplikasi yang dapat dilihat pengguna. Pengguna memberikan masukan dengan memilih menu Pelaksanaan Haji sehingga aplikasi akan menjalankan methode MenuPelaksanaan untuk menampilkan menu Pelaksanaan Haji. Selanjutnya pengguna memilih tombol
Niat Haji untuk menjalankannya digunakan methode Niat Haji dan methode onCreate menampilkan menu pengertian dari niat haji.

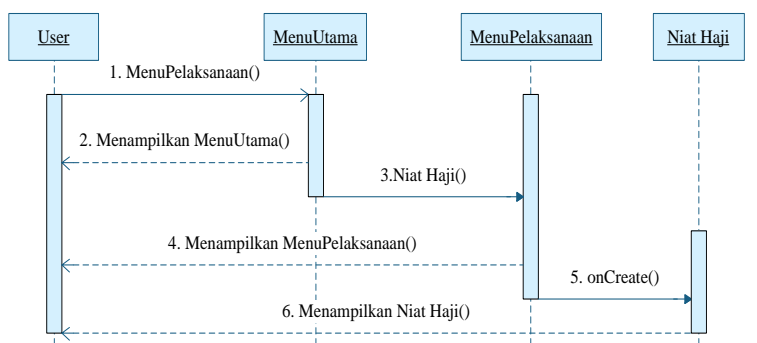

Gambar 6. Sequence Diagram Niat Haji

\subsection{Sequence Diagram Doa haji}

Sequence diagram menu Doa Haji ditunjukan oleh Gambar 3.25. Pada Gambar 3.25 terlihat bahwa pada saat aplikasi dibuka menampilkan menu Utama aplikasi yang dapat dilihat pengguna. Pengguna memberikan masukan dengan memilih menu Doa Haji sehingga aplikasi akan menjalankan methode MenuDoa dan methode onCreate untuk menampilkan menu Doa Haji. Pada menu Doa Haji terdapat tombol play untuk mengaktifkan methode onClick sehingga aplikasi akan memainkan audio bacaan doa haji yang telah dipilih.

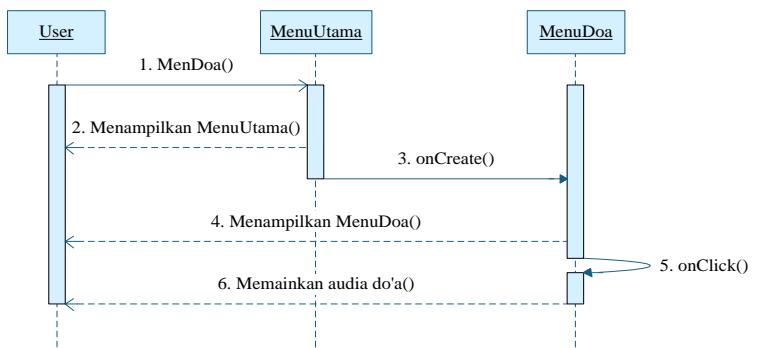

Gambar 7. Sequence Diagram Doa Haji

\subsection{Sequence Diagram Jadwal Shalat}

Sequence diagram menu Jadwal Shalat ditunjukan oleh Gambar 8. Pada Gambar 8 terlihat bahwa pada saat aplikasi dibuka menampilkan menu Utama aplikasi yang dapat dilihat pengguna. Pengguna memberikan masukan dengan memilih menu Jadwal Shalat sehingga aplikasi akan menjalankan methode MenuJadwal dan methode onCreate untuk menampilkan menu jadwal shalat lima waktu. Pada menu Jadwal Shalat terdapat alarm yang otomatis berbunyi jika waktu sholat telah tiba.

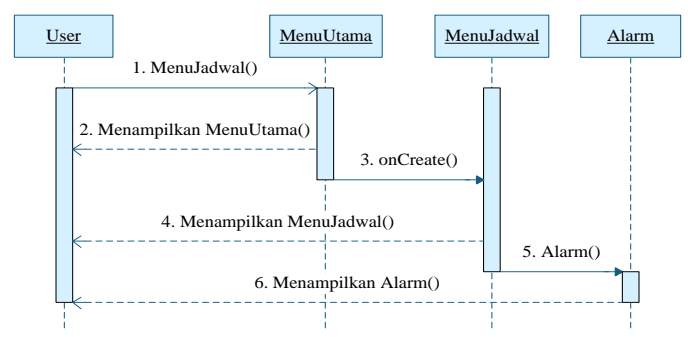

Gambar 8. Sequence Diagram Jadwal Shalat

\subsection{Sequence Diagram Tentang}

Sequence diagram menu Tentang ditunjukan oleh Gambar 9. Pada Gambar 9 terlihat bahwa pada saat aplikasi dibuka menampilkan menu Utama aplikasi yang dapat dilihat pengguna. Pengguna memberikan masukan dengan memilih 
menu Tentang sehingga aplikasi akan menjalankan methode MenuTentang dan methode onCreate untuk menampilkan menu Tentang yang berisikan tentang aplikasi panduan haji.

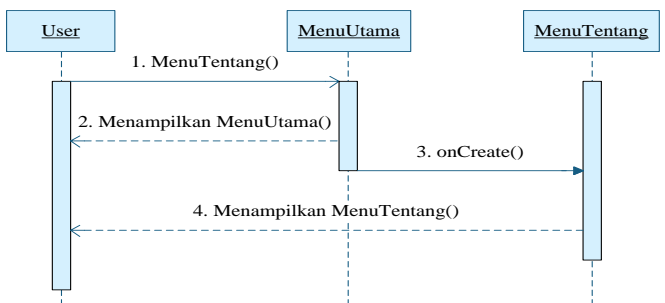

Gambar 9. Sequence Diagram Tentang

\subsection{Diagram Kelas}

Class adalah sebuah spesifikasi yang jika diinstansiasi akan menghasilkan sebuah objek dan merupakan inti dari pengembangan dan desain berorientasi objek. Class menggambarkan keadaan (atribut/properti) suatu sistem, sekaligus menawarkan layanan untuk memanipulasi keadaan tersebut (metode/fungsi).

\section{Hasil dan Pembahasan}

\section{Implementasi Antarmuka}

Implementasi antarmuka merupakan penerapan dari rancangan antarmuka Aplikasi Panduan Ibadah Haji. Implementasi antarmuka yang menarik dan pengguna sangat penting dalam membangun sebuah aplikasi. Dengan antarmuka yang menarik dan pengguna dapat memberikan daya tarik kepada pengguna untuk menggunakan aplikasi.

\subsection{Tampilan Menu Utama}

Tampilan menu Utama merupakan tampilan yang digunakan sebagai halaman awal Aplikasi Panduan Ibadah Haji. Tampilan menu Utama ini akan muncul setelah aplikasi dibuka. Pada tampilan menu Utama terdapat tombol-tombol untuk masuk ke halaman menu-menu yang lain. Tampilan Menu Utama dapat dilihat pada Gambar 10.

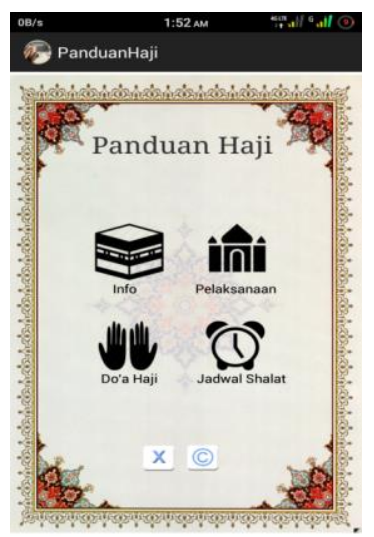

Gambar 10. Tampilan Menu Utama

\subsection{Tampilan Menu Info}

Tampilan menu Info merupakan tampilan yang menjelaskan berbagai informasi mengenai ibadah haji. Tombol-tombol yang tersedia pada menu Info akan menjelaskan mengenai ilmu dasar dalam ibadah haji. Tampilan Menu Info dapat dilihat pada Gambar 11.

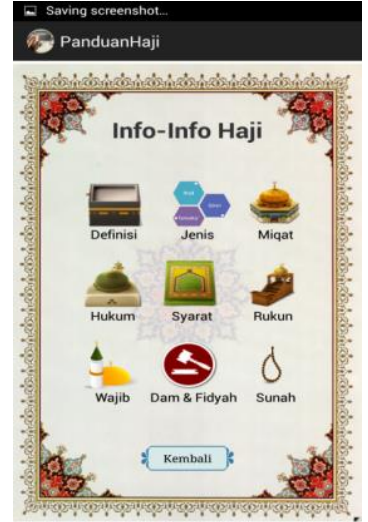

Gambar 11. Tampilan Menu Info

\subsection{Tampilan Halaman Penjelasan Pada Menu Info}

Tampilan halaman-halaman ini berisi penjelasan mengenai beberapa penjelasan yang ada pada menu Info ibadah haji. Tampilan halaman-halaman menu Info dapat dilihat pada Gambar 12.

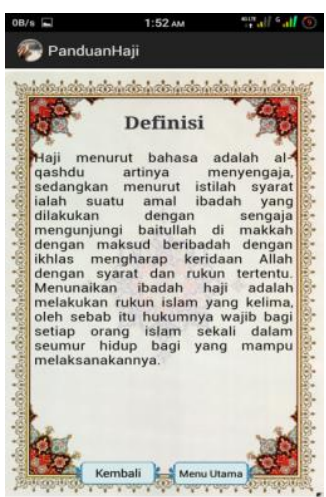

(a)

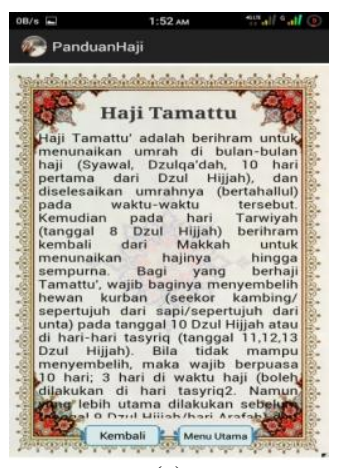

(c)

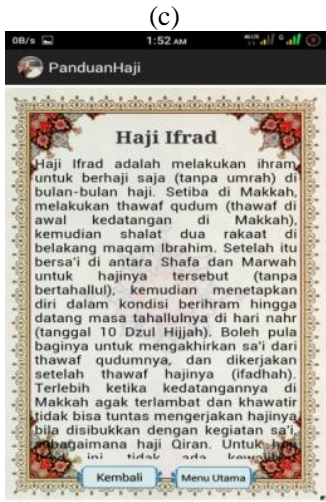

(e)

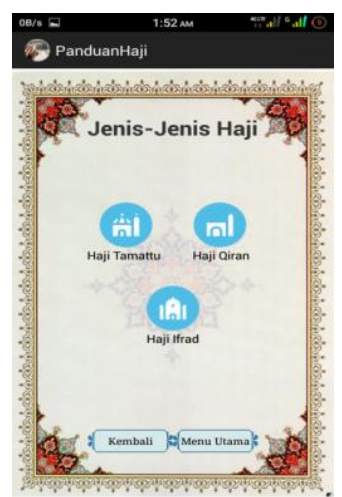

(b)

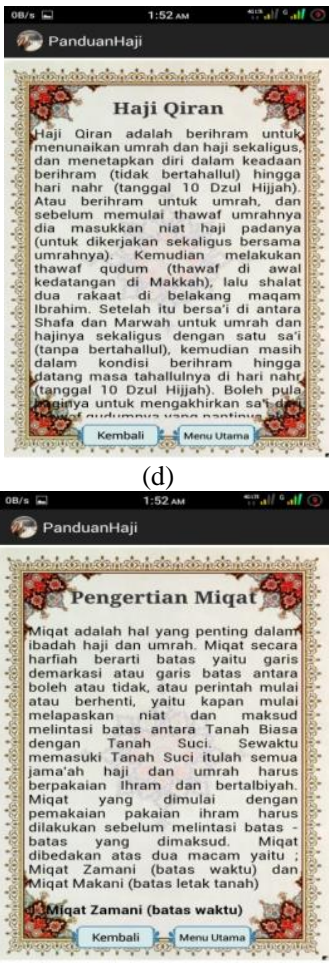

(f) 


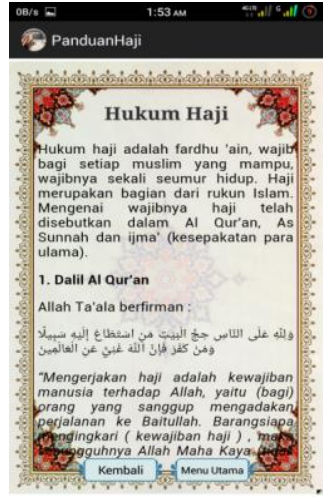

(g)

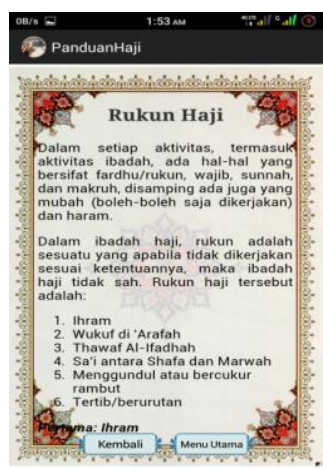

(i)

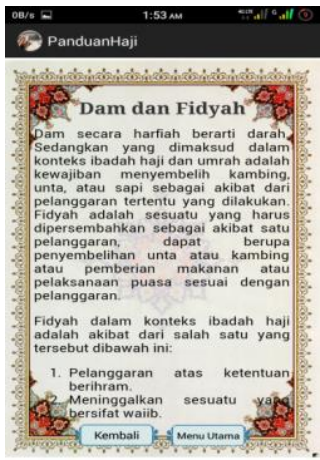

(k)

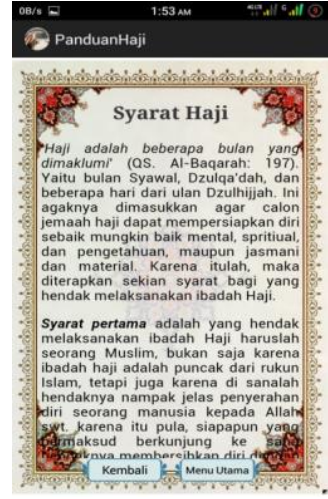

(h)

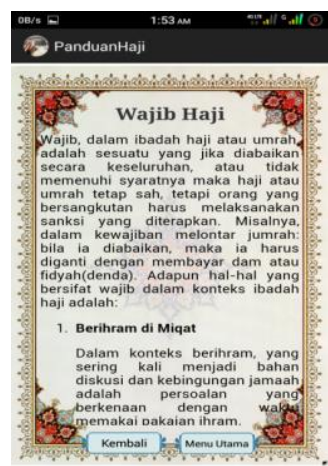

(j)

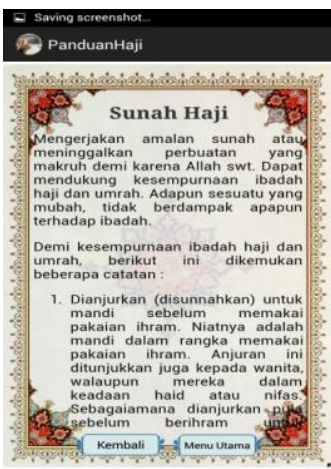

(1)
Gambar 12. (a) Tampilan halaman Definisi Haji, (b) Menu Jenis Haji, (c) Haji Tamattu, (d) Haji Qiran, (e) Haji Ifrad, (f) Miqat, (g) Hukum Haji, (h) Syarat Haji, (i) Rukun Haji, (j) Wajib Haji, (k) Dam dan Fidyah, dan (l) Sunah Haji

\subsection{Tampilan Menu Pelaksanaan}

Tampilan halaman menu Pelaksanaan berisi penjelasan mengenai kegiatan-kegiatan umum dalam melaksanakan ibadah haji. Tampilan Menu Pelaksanaan dapat dilihat pada Gambar 13.

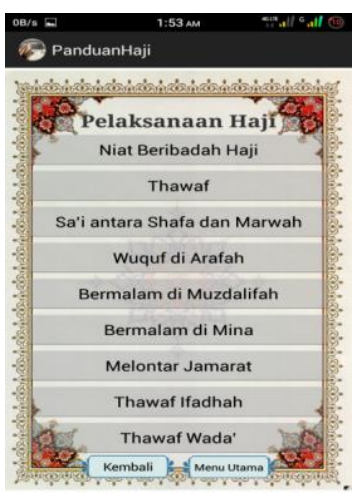

Gambar 13. Tampilan Menu Pelaksanaan

\subsection{Tampilan Halaman Penjelasan Menu Pelaksanaan}

Tampilan halaman ini berisi penjelasan mengenai beberapa kegiatan ibadah haji yang ada pada menu Pelaksanaan ibadah haji. Tampilan halaman-halaman pada menu Pelaksanaan Haji dapat dilihat pada Gambar 14.

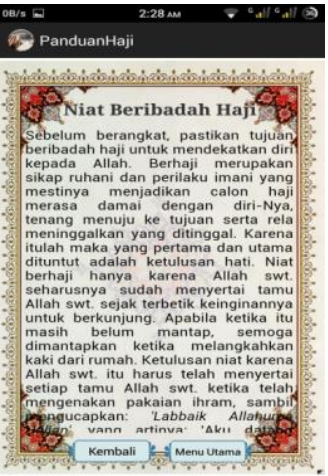

(a)

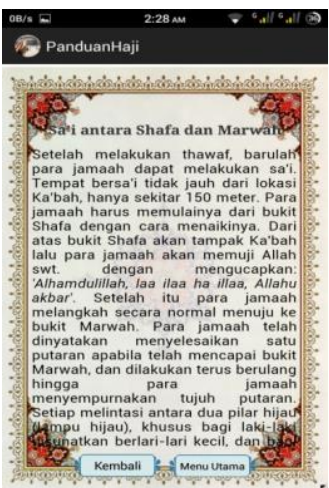

(c)

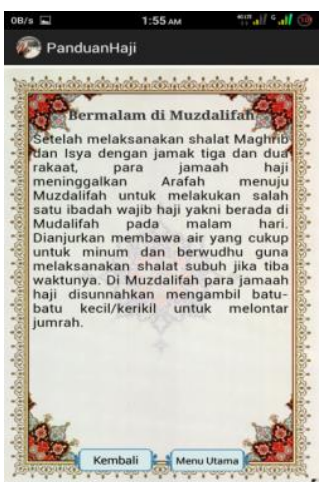

(e)

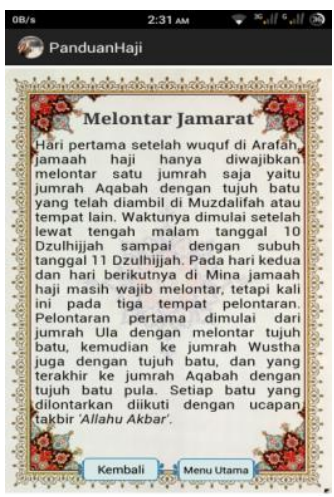

(g)

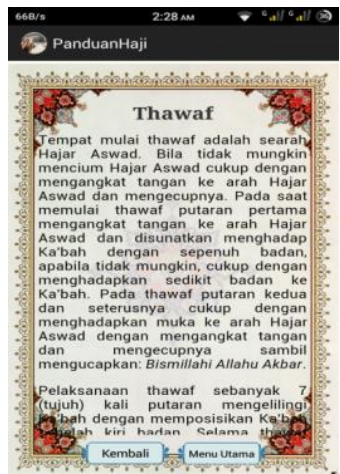

(b)

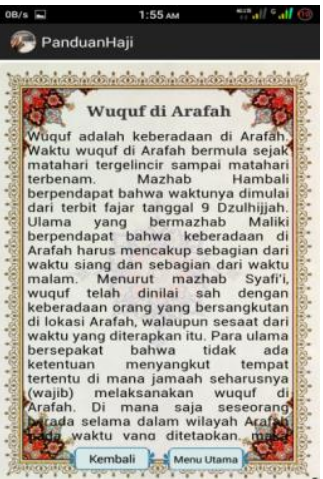

(d)

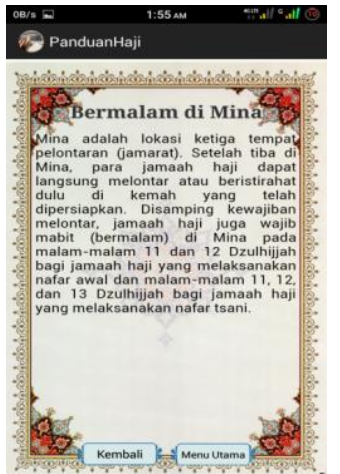

(f)

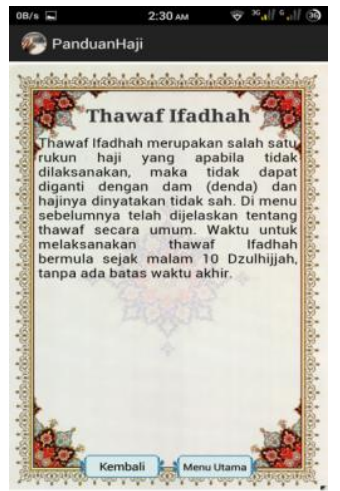

(h) 


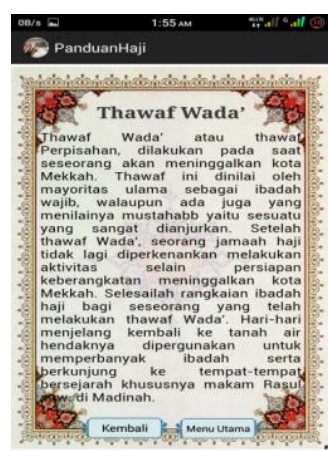

(i)

Gambar 14. (a) Tampilan halaman Niat Haji, (b) Thawaf, (c) Sa'i, (d) Wuquf, (e) Bermalam di Muzdalifah, (f) Bermalam di Mina, (g) Melontar Jamarat, (h) Thawaf Ifadhah, dan (i) Thawaf Wada'

\subsection{Tampilan Menu Doa Haji}

Tampilan halaman menu Doa Haji berisikan mengenai doa-doa seputar ibadah haji dan dilengkapi juga dengan bacaan dan audio bacaan doa. Tampilan Menu Doa Haji dapat dilihat pada Gambar 15.

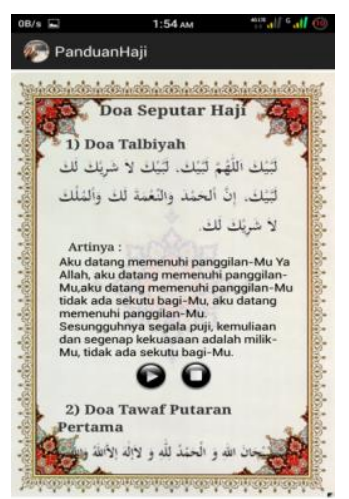

Gambar 15. Tampilan Menu Doa-Doa Haji

\subsection{Tampilan Menu Jadwal Shalat}

Tampilan halaman menu Jadwal Shalat berisikan informasi jadwal shalat lima waktu yang apabila waktu shalat telah tiba maka pengingat berupa suara azan akan muncul. Tampilan Menu Jadwal Shalat dapat dilihat pada Gambar 16.

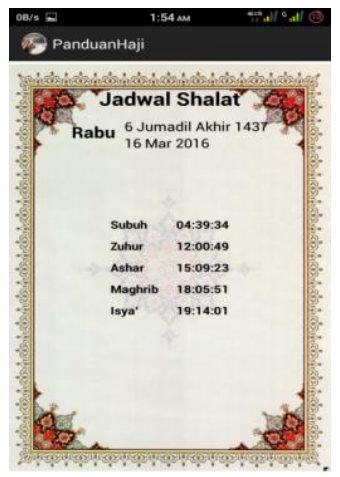

(a)

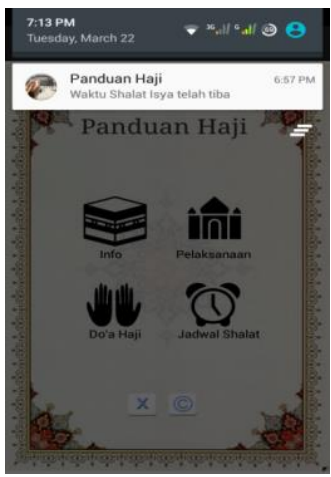

(b)
Gambar 16. (a) Tampilan Jadwal Shalat, (b) Tampilang Pengingat

\subsection{Tampilan Menu Tentang}

Tampilan halaman menu Tentang berisi mengenai tentang aplikasi. Tampilan Menu Tentang dapat dilihat pada Gambar 17.

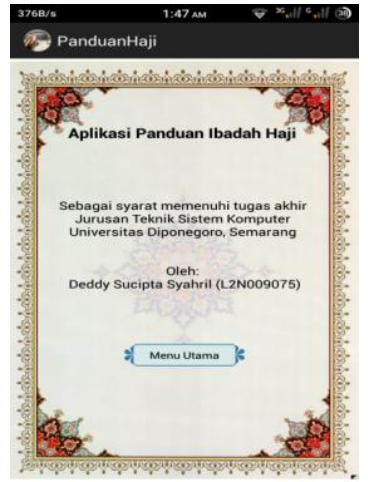

Gambar 17. Tampilan Menu Tentang

\section{Pengujian Black-Box}

Pengujian black-box adalah pengujian aspek fundamental sistem tanpa memperhatikan struktur logika internal perangkat lunak. Metode ini digunakan untuk mengetahui apakah perangkat lunak berfungsi dengan benar. Pengujian black-box merupakan metode perancangan data uji yang didasarkan pada spesifikasi perangkat lunak. Data uji dibangkitkan, dieksekusi pada perangkat lunak dan kemudian keluaran dari perangkat lunak dicek apakah telah sesuai dengan yang diharapkan. Pengujian black-box dari sistem yang dibangun pada tugas akhir ini dapat dilihat pada Tabel 1.

Tabel 1. Pengujian Sistem

\begin{tabular}{|c|c|c|c|}
\hline Pengujian & $\begin{array}{c}\text { Bentuk } \\
\text { Pengujian }\end{array}$ & $\begin{array}{l}\text { Hasil Yang } \\
\text { Diharapkan }\end{array}$ & $\begin{array}{c}\text { Hasil } \\
\text { Uji }\end{array}$ \\
\hline $\begin{array}{c}\text { Menu } \\
\text { Utama }\end{array}$ & $\begin{array}{l}\text { Pengguna } \\
\text { membuka } \\
\text { aplikasi } \\
\text { panduan } \\
\text { ibadah haji. }\end{array}$ & $\begin{array}{l}\text { Sistem } \\
\text { Menampilkan } \\
\text { halaman menu } \\
\text { Utama. }\end{array}$ & Berhasil \\
\hline Menu Info & $\begin{array}{l}\text { Pengguna } \\
\text { mengklik } \\
\text { menu Info } \\
\text { pada menu } \\
\text { Utama. }\end{array}$ & $\begin{array}{l}\text { Sistem } \\
\text { menampilkan } \\
\text { menu Info } \\
\text { dengan } \\
\text { beberapa menu } \\
\text { di dalamnya. }\end{array}$ & Berhasil \\
\hline $\begin{array}{c}\text { Menu } \\
\text { Definisi }\end{array}$ & $\begin{array}{l}\text { Pengguna } \\
\text { mengklik } \\
\text { menu } \\
\text { Definisi pada } \\
\text { menu Info. }\end{array}$ & $\begin{array}{l}\text { Sistem } \\
\text { menampilkan } \\
\text { halaman } \\
\text { definisi dari } \\
\text { ibadah haji. }\end{array}$ & Berhasil \\
\hline Menu Jenis & $\begin{array}{l}\text { Pengguna } \\
\text { mengklik } \\
\text { menu Jenis } \\
\text { pada menu } \\
\text { Info. }\end{array}$ & $\begin{array}{l}\text { Sistem } \\
\text { menampilkan } \\
\text { menu Jenis } \\
\text { dengan } \\
\text { beberapa menu } \\
\text { didalamnya. }\end{array}$ & Berhasil \\
\hline $\begin{array}{c}\text { Menu Haji } \\
\text { Tamattu }\end{array}$ & $\begin{array}{l}\text { Pengguna } \\
\text { mengklik } \\
\text { menu Haji } \\
\text { Tamattu } \\
\text { pada menu } \\
\text { Jenis. }\end{array}$ & $\begin{array}{l}\text { Sistem } \\
\text { menampilkan } \\
\text { halaman } \\
\text { pengertian dari } \\
\text { jenis haji } \\
\text { tamattu di } \\
\text { dalam ibadah } \\
\text { haji. }\end{array}$ & Berhasil \\
\hline
\end{tabular}




\begin{tabular}{|c|c|c|c|}
\hline $\begin{array}{l}\text { Menu Haji } \\
\text { Qiran }\end{array}$ & $\begin{array}{l}\text { Pengguna } \\
\text { mengklik } \\
\text { menu Haji } \\
\text { Qiran pada } \\
\text { menu Jenis. }\end{array}$ & $\begin{array}{l}\text { Sistem } \\
\text { menampilkan } \\
\text { halaman } \\
\text { pengertian dari } \\
\text { jenis haji qiran } \\
\text { di dalam } \\
\text { ibadah haji. }\end{array}$ & Berhasil \\
\hline $\begin{array}{l}\text { Menu Haji } \\
\text { Ifrad }\end{array}$ & $\begin{array}{l}\text { Pengguna } \\
\text { mengklik } \\
\text { menu Haji } \\
\text { Ifrad pada } \\
\text { menu Jenis. }\end{array}$ & $\begin{array}{l}\text { Sistem } \\
\text { menampilkan } \\
\text { halaman } \\
\text { pengertian dari } \\
\text { jenis haji ifrad } \\
\text { di dalam } \\
\text { ibadah haji. }\end{array}$ & Berhasil \\
\hline Menu Miqat & $\begin{array}{l}\text { Pengguna } \\
\text { mengklik } \\
\text { menu Miqat } \\
\text { pada menu } \\
\text { Info. }\end{array}$ & $\begin{array}{l}\text { Sistem } \\
\text { menampilkan } \\
\text { halaman } \\
\text { pembahasan } \\
\text { mengenai } \\
\text { pengertian } \\
\text { miqat dalam } \\
\text { ibadah haji. } \\
\end{array}$ & Berhasil \\
\hline $\begin{array}{c}\text { Menu } \\
\text { Hukum }\end{array}$ & $\begin{array}{l}\text { Pengguna } \\
\text { mengklik } \\
\text { menu } \\
\text { Hukum pada } \\
\text { menu Info. }\end{array}$ & $\begin{array}{l}\text { Sistem } \\
\text { menampilkan } \\
\text { halaman } \\
\text { pembahasan } \\
\text { mengenai } \\
\text { hukum-hukum } \\
\text { dalam ibadah } \\
\text { haji. }\end{array}$ & Berhasil \\
\hline $\begin{array}{l}\text { Menu } \\
\text { Syarat }\end{array}$ & $\begin{array}{l}\text { Pengguna } \\
\text { mengklik } \\
\text { menu Syarat } \\
\text { pada menu } \\
\text { Info. }\end{array}$ & $\begin{array}{l}\text { Sistem } \\
\text { menampilkan } \\
\text { halaman } \\
\text { pembahasan } \\
\text { mengenai } \\
\text { syarat-syarat } \\
\text { dalam ibadah } \\
\text { haji. } \\
\end{array}$ & Berhasil \\
\hline $\begin{array}{l}\text { Menu } \\
\text { Rukun }\end{array}$ & $\begin{array}{l}\text { Pengguna } \\
\text { mengklik } \\
\text { menu Rukun } \\
\text { pada menu } \\
\text { Info. }\end{array}$ & $\begin{array}{l}\text { Sistem } \\
\text { menampilkan } \\
\text { halaman } \\
\text { pembahasan } \\
\text { mengenai } \\
\text { rukun-rukun } \\
\text { dalam ibadah } \\
\text { haji. }\end{array}$ & Berhasil \\
\hline Menu Wajib & $\begin{array}{l}\text { Pengguna } \\
\text { mengklik } \\
\text { menu Wajib } \\
\text { pada menu } \\
\text { Info. }\end{array}$ & $\begin{array}{l}\text { Sistem } \\
\text { menampilkan } \\
\text { halaman } \\
\text { pembahasan } \\
\text { mengenai } \\
\text { kewajiban- } \\
\text { kewajiban } \\
\text { dalam ibadah } \\
\text { haji. } \\
\end{array}$ & Berhasil \\
\hline $\begin{array}{l}\text { Menu Dam } \\
\text { dan Fidyah }\end{array}$ & $\begin{array}{l}\text { Pengguna } \\
\text { mengklik } \\
\text { menu Dam } \\
\text { dan Fidyah } \\
\text { pada menu } \\
\text { Info. }\end{array}$ & $\begin{array}{l}\text { Sistem } \\
\text { menampilkan } \\
\text { halaman } \\
\text { pembahasan } \\
\text { mengenai dam } \\
\text { dan fidyah } \\
\text { dalam ibadah } \\
\text { haji. }\end{array}$ & Berhasil \\
\hline
\end{tabular}

\begin{tabular}{|c|c|c|c|}
\hline Menu Sunah & $\begin{array}{l}\text { Pengguna } \\
\text { mengklik } \\
\text { menu Sunah } \\
\text { pada menu } \\
\text { Info. }\end{array}$ & $\begin{array}{l}\text { Sistem } \\
\text { menampilkan } \\
\text { halaman } \\
\text { pembahasan } \\
\text { mengenai } \\
\text { rukun-rukun } \\
\text { dalam ibadah } \\
\text { haji. } \\
\end{array}$ & Berhasil \\
\hline $\begin{array}{c}\text { Menu Doa } \\
\text { Haji }\end{array}$ & $\begin{array}{l}\text { Pengguna } \\
\text { mengklik } \\
\text { menu Doa } \\
\text { Haji pada } \\
\text { menu Utama. }\end{array}$ & $\begin{array}{l}\text { Sistem } \\
\text { menampilkan } \\
\text { doa-doa } \\
\text { seputar ibadah } \\
\text { haji dan } \\
\text { berisikan audio } \\
\text { bacaan doa. }\end{array}$ & Berhasil \\
\hline $\begin{array}{l}\text { Audio contoh } \\
\text { bacaan }\end{array}$ & $\begin{array}{l}\text { Pengguna } \\
\text { mengklik } \\
\text { tombol play } \\
\text { pada bacaan } \\
\text { doa-doa haji. }\end{array}$ & $\begin{array}{l}\text { Sistem } \\
\text { memainkan } \\
\text { audio contoh } \\
\text { bacaan dan } \\
\text { terjemahannya } \\
\text { dari doa-doa } \\
\text { seputar ibadah } \\
\text { haji. }\end{array}$ & Berhasil \\
\hline $\begin{array}{c}\text { Menu } \\
\text { Pelaksanaan }\end{array}$ & $\begin{array}{l}\text { Pengguna } \\
\text { mengklik } \\
\text { menu } \\
\text { Pelaksanaan } \\
\text { pada menu } \\
\text { Utama. }\end{array}$ & $\begin{array}{l}\text { Sistem } \\
\text { menampilkan } \\
\text { menu } \\
\text { Pelaksanaan } \\
\text { dengan } \\
\text { beberapa menu } \\
\text { di dalamnya. }\end{array}$ & Berhasil \\
\hline $\begin{array}{c}\text { Menu Niat } \\
\text { Haji }\end{array}$ & $\begin{array}{l}\text { Pengguna } \\
\text { mengklik } \\
\text { menu Niat } \\
\text { Haji pada } \\
\text { menu } \\
\text { Pelaksanaan. }\end{array}$ & $\begin{array}{l}\text { Sistem } \\
\text { menampilkan } \\
\text { halaman } \\
\text { pembahasan } \\
\text { mengenai niat } \\
\text { dalam ibadah } \\
\text { haji. }\end{array}$ & Berhasil \\
\hline $\begin{array}{l}\text { Menu } \\
\text { Thawaf }\end{array}$ & $\begin{array}{l}\text { Pengguna } \\
\text { mengklik } \\
\text { menu } \\
\text { Thawaf pada } \\
\text { menu } \\
\text { Pelaksanaan. }\end{array}$ & $\begin{array}{l}\text { Sistem } \\
\text { menampilkan } \\
\text { halaman } \\
\text { pembahasan } \\
\text { kegiatan } \\
\text { thawaf dalam } \\
\text { ibadah haji. } \\
\end{array}$ & Berhasil \\
\hline Menu Sa'i & $\begin{array}{l}\text { Pengguna } \\
\text { mengklik } \\
\text { menu Sa'i } \\
\text { pada menu } \\
\text { Pelaksanaan. }\end{array}$ & $\begin{array}{l}\text { Sistem } \\
\text { menampilkan } \\
\text { halaman } \\
\text { pembahasan } \\
\text { kegiatan sa'i } \\
\text { dalam ibadah } \\
\text { haji. } \\
\end{array}$ & Berhasil \\
\hline $\begin{array}{l}\text { Menu } \\
\text { Wuquf di } \\
\text { Arafah }\end{array}$ & $\begin{array}{l}\text { Pengguna } \\
\text { mengklik } \\
\text { menu Wuquf } \\
\text { di Arafah } \\
\text { pada menu } \\
\text { Pelaksanaan. }\end{array}$ & $\begin{array}{l}\text { Sistem } \\
\text { menampilkan } \\
\text { halaman } \\
\text { pembahasan } \\
\text { kegiatan wuquf } \\
\text { dalam ibadah } \\
\text { haji. }\end{array}$ & Berhasil \\
\hline $\begin{array}{c}\text { Menu } \\
\text { Bermalam } \\
\text { di } \\
\text { Muzdalifah }\end{array}$ & $\begin{array}{l}\text { Pengguna } \\
\text { mengklik } \\
\text { menu } \\
\text { Bermalam di } \\
\text { Muzdalifah } \\
\text { pada menu } \\
\text { Pelaksanaan. }\end{array}$ & $\begin{array}{l}\text { Sistem } \\
\text { menampilkan } \\
\text { halaman } \\
\text { pembahasan } \\
\text { kegiatan } \\
\text { bermalam di } \\
\text { Muzdalifah }\end{array}$ & Berhasil \\
\hline
\end{tabular}

Jurnal Teknologi dan Sistem Komputer, 4(3), 2016, 448 


\begin{tabular}{|c|c|c|c|}
\hline & & $\begin{array}{l}\text { dalam ibadah } \\
\text { haji. }\end{array}$ & \\
\hline $\begin{array}{c}\text { Menu } \\
\text { Bermalam } \\
\text { di Mina }\end{array}$ & $\begin{array}{l}\text { Pengguna } \\
\text { mengklik } \\
\text { menu } \\
\text { Bermalam di } \\
\text { Mina pada } \\
\text { menu } \\
\text { Pelaksanaan. }\end{array}$ & $\begin{array}{l}\text { Sistem } \\
\text { menampilkan } \\
\text { halaman } \\
\text { pembahasan } \\
\text { kegiatan } \\
\text { bermalam di } \\
\text { Mina dalam } \\
\text { ibadah haji. }\end{array}$ & Berhasil \\
\hline $\begin{array}{c}\text { Menu } \\
\text { Melontar } \\
\text { Jamarat }\end{array}$ & $\begin{array}{l}\text { Pengguna } \\
\text { mengklik } \\
\text { menu } \\
\text { Melontar } \\
\text { Jamarat } \\
\text { pada menu } \\
\text { Pelaksanaan. }\end{array}$ & $\begin{array}{l}\text { Sistem } \\
\text { menampilkan } \\
\text { halaman } \\
\text { pembahasan } \\
\text { kegiatan } \\
\text { melontar } \\
\text { jamarat dalam } \\
\text { ibadah haji. }\end{array}$ & Berhasil \\
\hline $\begin{array}{c}\text { Menu } \\
\text { Thawaf } \\
\text { Ifadhah }\end{array}$ & $\begin{array}{l}\text { Pengguna } \\
\text { mengklik } \\
\text { menu } \\
\text { Thawaf } \\
\text { Ifadhah pada } \\
\text { menu } \\
\text { Pelaksanaan. }\end{array}$ & $\begin{array}{l}\text { Sistem } \\
\text { menampilkan } \\
\text { halaman } \\
\text { pembahasan } \\
\text { kegiatan } \\
\text { thawaf ifadhah } \\
\text { dalam ibadah } \\
\text { haji. }\end{array}$ & Berhasil \\
\hline $\begin{array}{l}\text { Menu } \\
\text { Thawaf } \\
\text { Wada' }\end{array}$ & $\begin{array}{l}\text { Pengguna } \\
\text { mengklik } \\
\text { menu } \\
\text { Thawaf } \\
\text { Wada' pada } \\
\text { menu } \\
\text { Pelaksanaan. }\end{array}$ & $\begin{array}{l}\text { Sistem } \\
\text { menampilkan } \\
\text { halaman } \\
\text { pembahasan } \\
\text { kegiatan } \\
\text { thawaf wada' } \\
\text { dalam ibadah } \\
\text { haji. } \\
\end{array}$ & Berhasil \\
\hline $\begin{array}{l}\text { Menu } \\
\text { Jadwal } \\
\text { Shalat }\end{array}$ & $\begin{array}{l}\text { Pengguna } \\
\text { mengklik } \\
\text { menu Jadwal } \\
\text { Shalat pada } \\
\text { menu Utama. }\end{array}$ & $\begin{array}{l}\text { Sistem } \\
\text { menampilkan } \\
\text { halaman } \\
\text { jadwal shalat } \\
\text { lima waktu. }\end{array}$ & Berhasil \\
\hline $\begin{array}{c}\text { Pengingat } \\
\text { waktu shalat } \\
\text { lima waktu }\end{array}$ & $\begin{array}{l}\text { Menyamakan } \\
\text { waktu shalat } \\
\text { di menu } \\
\text { Jadwal } \\
\text { Shalat } \\
\text { dengan waktu } \\
\text { di telepon } \\
\text { seluler } \\
\text { pengguna. }\end{array}$ & $\begin{array}{l}\text { Sistem } \\
\text { memberikan } \\
\text { pengingat } \\
\text { waktu shalat } \\
\text { berupa suara } \\
\text { azan. }\end{array}$ & Berhasil \\
\hline $\begin{array}{c}\text { Menu } \\
\text { Tentang }\end{array}$ & $\begin{array}{l}\text { Pengguna } \\
\text { mengklik } \\
\text { menu } \\
\text { Tentang (C) } \\
\text { pada menu } \\
\text { Utama. }\end{array}$ & $\begin{array}{l}\text { Menampilkan } \\
\text { halaman } \\
\text { informasi } \\
\text { tentang } \\
\text { aplikasi. }\end{array}$ & Berhasil \\
\hline $\begin{array}{l}\text { Tombol } \\
\text { Keluar }\end{array}$ & $\begin{array}{l}\text { Pengguna } \\
\text { mengklik } \\
\text { tombol } \\
\text { Keluar }(\mathbf{x}) \\
\text { pada menu } \\
\text { Utama. } \\
\end{array}$ & $\begin{array}{l}\text { Menampilkan } \\
\text { notifikasi } \\
\text { keluar aplikasi } \\
\text { : Ya dan Tidak }\end{array}$ & Berhasil \\
\hline
\end{tabular}

\section{KeSimpulan}

Dari hasil pengujian dan analisis Aplikasi Panduan Ibadah Haji Berbasis Android dapat disimpulkan hal-hal yaitu, berdasarkan pengujian yang dilakukan oleh beberapa responden, dapat disimpulkan bahwa aplikasi Panduan Ibadah Haji mudah dijalankan dan bermanfaat sebagai media pembelajaran tentang ibadah haji. Aplikasi Panduan Ibadah Haji ini dapat berjalan dengan baik pada perangkat dengan sistem operasi Android minimal versi 4.2 (Jelly Bean) dan maksimal Android 5.1 (Lollipop) sesuai dengan hasil percobaan dengan kapasitas penyimpanan yang tersedia minimal 25 MB. Berdasarkan pengujian black-box, tomboltombol dan fungsi-fungsi yang terdapat pada aplikasi Panduan Ibadah Haji dapat berfungsi dengan baik dan sesuai dengan fungsionalitasnya masing-masing.

Berdasarkan hasil pengujian Aplikasi Panduan Ibadah Haji Berbasis Android, dapat diberikan beberapa saran yaitu aplikasi Panduan Ibadah Haji perlu dikembangkan lagi dengan menambah materi umrah, aplikasi Panduan Ibadah Haji akan lebih baik apabila ada penambahan fitur-fitur yang lebih menarik misalnya penunjuk arah ke lokasi-lokasi penting dalam ibadah haji, dan aplikasi Panduan Ibadah Haji akan lebih baik apabila dikembangkan juga sebagai aplikasi cross-platform, misalnya pada Blackberry OS dan IOS.

\section{UCAPAN TERIMA KASIH}

Terima kasih disampaikan kepada Program Studi Komputer Undip yang telah mendanai keberlangsungan jurnal ini.

\section{DAFTar Pustaka}

[1] Anugraha, Rinto., 2011. Kalender Julian, Kalender Gregorian dan Julian Day, (online), (http://rinto.staff.ugm.ac.id/kalender-julian-kalendergregorian-dan-julian-day).

[2] Cinar, O., 2012. Android Apps with Eclipse, Jakarta: Apress.

[3] Darytamo, Budi, Sri Widayanti., 2007. Pemrograman Berorientasi Obyek dengan Java 2 Platform Micro Edition ( J2ME ), Bandung: Java Competency Center-ITB.

[4] Djamil, Abdul., 2014. Doa dan Dzikir Manasik Haji dan Umrah, Jakarta: Kemenag.

[5] Djamil, Abdul., 2014. Tuntutan Manasik Haji dan Umrah, Jakarta: Kemenag.

[6] Pressman, Roger S., 2002. Rekayasa Perangkat Lunak (Pendekatan Praktis), Yogyakarta: Andi.

[7] Putra, A.A., 2012. Praktis Android A-Z, Lubuklinggau: Graha Ilmu.

[8] Rasis, Jundi., 2014. Pembuatan Aplikasi M-Learning untuk Pembelajaran Tajwid Berbasis Android, Semarang, Skripsi S-1 Universitas Diponegoro: Tidak diterbitkan.

[9] Safaat H, N., 2011. ANDROID Pemrograman Aplikasi Mobile Smartphone dan Tablet PC berbasis Android, Bandung: Informatika.

[10] Shihab, Q.M., 2012. Haji dan Umrah bersama M. Quraish Shihab, Tangerang: Lentera Hati. 